\title{
Research
}

\section{Tending for Cattle: Traditional Fire Management in Ethiopian Montane Heathlands}

\author{
$\underline{\text { Maria U. Johansson }}^{1}$, Masresha Fetene $^{2}$, Anders Malmer $^{1}{ }^{1}$ and $^{\text {Anders Granström }}{ }^{1}$
}

\begin{abstract}
Fire has long been a principal tool for manipulating ecosystems, notably for pastoralist cultures, but in modern times, fire use has often been a source of conflicts with state bureaucracies. Despite this, traditional fire management practices have rarely been examined from a perspective of fire behavior and fire effects, which hampers dialogue on management options. In order to analyze the rationale for fire use, its practical handling, and ecological effects in high-elevation ericaceous heathlands in Ethiopia, we used three different information sources: interviews with pastoralists, field observations of fires, and analysis of vegetation age structure at the landscape level. The interviews revealed three primary reasons for burning: increasing the grazing value, controlling a toxic caterpillar, and reducing predator attacks. Informants were well aware of critical factors governing fire behavior, such as slope, wind, vertical and horizontal fuel structure, and fuel moisture. Recent burns (1-4 years since fire) were used as firebreaks to control the size of individual burns, which resulted in a mosaic of vegetation of different ages. The age structure indicated an average fire return interval of $\sim 10$ years. At these elevations $(>3500 \mathrm{~m})$, the dry period is unreliable, with occasional rains. Of all observed fires, $83 \%$ were ignited during very high Fire Weather Index levels, reached during only $11 \%$ of all days of the year. Burning is illegal, but if this ban was respected, our data suggest that the Erica shrubs would grow out of reach of cattle within a few years only, creating a dense and continuous canopy. This would also create a risk of large high-intensity wildfires since the landscape is virtually devoid of natural fuel breaks. Under the present management regime, this heathland ecosystem should be quite resilient to degradation by fire due to a relatively slow fuel buildup (limiting fire intervals) and an effective regrowth of Erica shoots. Nevertheless, if burning is done during severe drought, there may be a risk of smoldering fires killing the lignotubers. Given the intimate knowledge of fire behavior and fire effects among these pastoralists, it should be possible to develop a fire management plan that can sustain the present land use and ecosystem, and be sanctioned by both authorities and the local community.
\end{abstract}

Key Words: anthropogenic fire; Erica arborea; Erica trimera; fire behavior; fire ecology; forage shrub systems; pastoralist land use; traditional ecological knowledge

\section{INTRODUCTION}

Fire is a natural ecological process and often an integral component of ecosystem function and diversity (Bowman et al. 2009). At the same time, fire is a tool that has been used by humans over millennia to modify vegetation according to their needs (Lewis 1989, Bowman 1998). It can be assumed that traditional fire practices largely reflect the prevailing cultural use of the landscape (Keeley 2002, Bird et al. 2008, Granström and Niklasson 2008). However, today most states have a restrictive legislation towards fire practices (Kull 2004, Laris and Wardell 2006, Eriksen 2007, Solomon et al. 2007), and traditional fire use is also rapidly changing due to socioeconomic factors (Kepe and Scoones 1999, Métailié 2006). This is causing shifts in fire regimes, with potential adverse effects on ecosystems and livelihoods (Pausas and Keeley 2009, Shaffer 2010).

For pastoralists in particular, fire is often a necessary management tool since it is the most efficient way to control woody species and keep the vegetation short enough for grazing animals. There are surprisingly few studies that have analyzed traditional ecological knowledge regarding fire management in pastoralist cultures. Studies of savanna pastoralists in Africa, however, point to multiple reasons for burning, among which the need to rejuvenate pasture may be the most important (Angassa and Oba 2008, Butz 2009). Further, there can be a need to burn out fuels early in the fire season to create firebreaks and prevent high-intensity lateseason wildfires (Hough 1993, Mbow et al. 2000, Laris 2002).

In the forested southern highlands of Ethiopia, agriculture is limited at high elevations due to a severe temperature climate with frequent night frosts. Therefore, grazing is the main land use. Above $\sim 3300 \mathrm{~m}$ elevation, tree heather (Erica spp.) becomes increasingly dominant in the forest, and at $\sim 3500 \mathrm{~m}$ there is a distinct tree line above which the Erica is kept in a shrubby state through repeated burning by montane pastoralists (Miehe and Miehe 1994). This subalpine Erica scrub vegetation, hereafter referred to as the heathlands, has two co-dominant species: Erica arborea L. and Erica trimera (Engl.) Beentje (Gashaw et al. 2009). The heathland vegetation is highly flammable due to the small leaf size of the Erica species, their fine branching structure, the persistence of dead branches (Pereira et al. 1995), and the high calorific value of their foliage (Dimitrakopoulos and Panov 2001). Fire kills all above-ground biomass, but both Erica species regenerate

\footnotetext{
${ }^{1}$ Department of Forest Ecology and Management, Swedish University of Agricultural Sciences, ${ }^{2}$ Department of Biology, Addis Ababa University
} 
rapidly by re-sprouting from underground lignotubers (Wesche et al.2000). Young post-fire regeneration stages have a large proportion of perennial grasses and herbs (including Trifolium spp.) between the lignotubers. Both grass, herbs, and the young Erica shoots are consumed by cattle (Johansson et al. 2009).

Fire is a highly complex and potentially dangerous phenomenon, and modern fire management relies on a research-based understanding of fuels, fire behavior, and fire effects. In contrast, traditional fire knowledge must have evolved through a collective and gradual accumulation of experience, in accordance with other examples of traditional ecological knowledge (Berkes et al. 2000). One problem is that most studies of traditional fire management describe fire practices that were already abandoned or under considerable change (Lewis and Ferguson 1988, Storm and Shebitz 2006, Shaffer 2010), which hampers the analysis of people's understanding of fire, current fire regimes, and their ecological effects. In Ethiopia, burning of vegetation is nominally illegal (Melaku Bekele, personal communication), but law enforcement has been weak in remote areas such as Bale; therefore, active fire management is still being practiced. There is, however, growing concern regarding the sustainability of the current land use, and fire is generally seen by the authorities as purely destructive to the heathland ecosystem. These concerns might become further augmented by upcoming carbon storage issues (Roman-Cuesta et al. 2011). In this perspective, a deeper understanding of the traditional fire management and its rationale should assist any future development towards a more participatory management system for the heathlands. Traditional ecological knowledge from this "living" fire culture can also advance the understanding of historic fire cultures in similar ecosystems.

In this study we interviewed pastoralists in the Bale Mountains in order to elucidate their traditional knowledge of fire with regard to factors such as fuel structure, topography, and weather. We also documented the pastoralists' general management strategies, their burning techniques, and how they perceive the impact of burning on pasture quality. In order to corroborate the interview information and to quantify the present fire regime and its effects, we also analyzed the current vegetation age structure at the landscape level and made field observations of fire occurrence and fire weather during four consecutive dry periods.

\section{METHODS}

\section{Study area}

The study was conducted in the southern highlands of Ethiopia, in the Bale Zone of Oromia Regional state, in the districts of Adaba, Dodola, Ashena Robe, and Serofta, in an $\sim 50 \times 25 \mathrm{~km}$ area centered at $6^{\circ} 49^{\prime} \mathrm{N}, 39^{\circ} 15^{\prime} \mathrm{E}$. The Bale Mountains is an $\sim 2600 \mathrm{~km}^{2}$ mountain massif rising to a peak at $4377 \mathrm{~m}$. It is covered by subalpine forests from approximately $2700 \mathrm{~m}$ up to the tree line at $3500 \mathrm{~m}$, where tree-formed Erica spp. ( 11 m tall) revert to a shrubby heathland, which is maintained by repeated burning. The burning creates a heterogeneous landscape with vegetation patches in different stages of succession which are dominated by $E$. arborea and $E$. trimera shrubs, typically ranging from 0 to $2 \mathrm{~m}$ in height. The older stages have a dense multi-stem shrub canopy with moss covering the ground, whereas in the younger stages the re-sprouting Erica individuals are separated by a short-cropped lawn of grasses and herbs.

The bedrock consists of Tertiary basalts, weathering to dark brown to black silty loams high in soil organic matter and with a well-developed humus layer on top (Yimer et al. 2006). The climate is cool and moist with cold nights and warm days and with precipitation distributed throughout most of the year but with the major rain period occurring between June and October. There is a short dry season which normally lasts two to three months (December-January), but small amounts of precipitation sometime fall during the dry season. The dry season is characterized by more pronounced diurnal temperature fluctuations and common night frosts (Wesche et al. 2008). Inter-annual variation in rainfall is very large, and there are recurring inter-decadal droughts (Seleshi and Demaree 1995). These, however, affect the high altitudes less severely than the lowlands (Miehe and Miehe 1994). Temperature and rainfall is highly dependent on altitude and topography. In the study area, the mean daily maximum and minimum temperatures at $3500 \mathrm{~m}$ altitude were $\sim 14^{\circ} \mathrm{C}$ and $5^{\circ}$ $\mathrm{C}$, respectively, and the mean annual rainfall was $\sim 1740 \mathrm{~mm}$ (measured by us at two sites in 2005-2008).

The inhabitants are Oromo-speaking pastoralists who have lived in the area for many centuries (Huntingford 1955, Haberland 1963). There are no reliable population density data for the study area, but the annual population growth for the Bale Mountains is high (3.46\% between 1994 and 2007 [Anonymous 2012]). There are no dwellings above the tree line due to the harsh nighttime climate, but homesteads are scattered in the forests below. The heathlands are the main pasture area, although the forest is also used for grazing.

Livelihoods depend mainly on livestock, primarily cattle (Bos taurus indicus L.). Milk and butter are produced for sustenance, butter is sold at the weekly market, and occasionally a bull is sold for slaughter. Many households also rear a few sheep or goats. Cattle graze in small herds (ranging between 7 and 18 animals, with about one-third of them lactating cows [Gustafsson 2009]). During the daytime, they graze freely in the heathland (Fig. 1), without shepherds, whereas young calves, sheep, and goats are herded close to the settlements to protect them from predators (mainly common jackal [Canis aureus L.], spotted hyena [Crocuta crocuta Erxleben], and leopard [Panthera pardus L.]). Horses 
are also raised for transport and sale. There are no motor roads in the area, and horses are widely used for travel and transport. All livestock except mature bulls are kept close to the houses during nighttime, guarded by dogs against predators.

Fig. 1. Cattle in a 1-year-old stand of Erica spp. Some of the dead Erica stems from the pre-burn stand are still standing. Older and taller Erica is seen in the background.

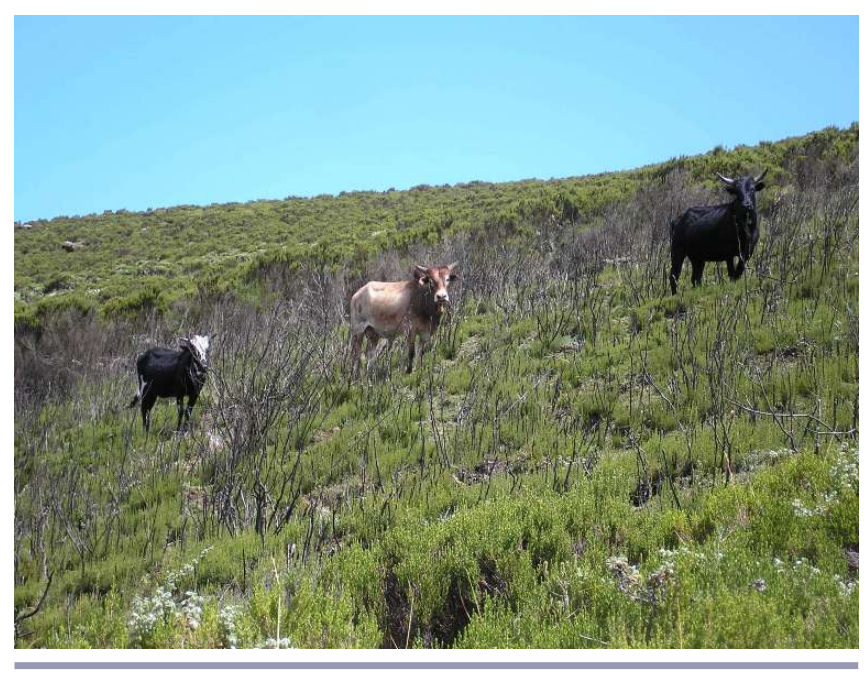

\section{Interviews}

We spent, in total, 249 days in the heathlands, during four dry seasons between 2005 and 2008, collecting data for different studies concerning fuel structure and vegetation response to fire and grazing. Interspersed with different vegetation studies, we conducted qualitative interviews with 18 informants who were utilizing the heathlands as pasture, in six different areas with a minimum $8 \mathrm{~km}$ inter-distance. We selected the informants by purposeful sampling in order to interview mainly persons experienced in fire use. Since we found out that burning is considered to be primarily a male task, we interviewed more men (14) than women (four). A further criterion was that the informants were not closely related or lived close to each other. The age of the informants ranged from 20 to $\sim 90$ years. We selected several old informants to get perspectives on past and current fire management. Informants represented all groups of the society in aspects of age, wealth, and gender. Wealth was assessed by the size of their cattle herds, number of wives, and homesteads, and whether or not they came from a former landlord family. A first interview was conducted in January 2006, seven interviews were done in the dry season 2006/2007, eight were conducted in the following dry season, and two were done in November 2008. By then we had achieved data saturation with regard to central questions on fire management.

We assured all informants anonymity. They were interviewed on separate occasions by one or two of the authors, with one local interpreter translating from Oromo to English. The interviews lasted about one hour, were recorded on a digital voice recorder, and were later translated by an independent interpreter who transcribed the Oromo language parts of the interviews into text, which we compared with the audio translations to detect possible discrepancies. All interpreters were native Oromo speakers and were fluent in English.

We used semi-directed interviews to avoid undue influence but still keep focus on the subject (Huntington 2000). The interviews started with a few general questions about subsistence and historical change with respect to livelihoods and the environment. The rest of the interview focused on a set of 24 enlarged photo prints (e.g., Collier and Collier 1986) of different features of the local landscapes, such as heathland vegetation of different structure and height, and different kinds of heathland fires and burn patterns, including a series of nine photos of Erica vegetation of different age since fire. In order to avoid defining the pictures and leading the thoughts of the informants, we always started by asking what they saw in the photo. Then we asked about Erica stand age and forage value, and if it could and should burn, and under what conditions. We asked about ignition and control, weather, fire behavior, safety measures, and sizes and quality of burns.

We complemented the semi-directed interviews with in-field interviews with two of the previously interviewed male informants. They were middle-aged ( 40 and 45 years old), had lived their whole lives in the area, and were currently actively engaged in fire management. During these interviews, we walked through the heathland and looked closely at soils, plants, and insects, and discussed fire behavior and effects in more detail. With one of these informants we also performed a burn (for which we had obtained legal permit) in order to document ignition techniques, which were also corroborated by observations at a distance, of a number of other burns. The information obtained during the in-field interviews was highly consistent and supported the information obtained from the semi-directed interviews.

None of the informants were hesitant to talk freely about fire, despite the fact that they also stated that burning is considered to be illegal. All informants (except one woman) had lived the largest part of their lives on the mountain and had a clear opinion about the effects of fire on pasture quality, and all had a good general understanding of fire behavior and burning practices.

All interview answers were coded and compiled into a spreadsheet together with the demographic data. We searched for patterns relative to informant category (e.g., gender, age, wealth), but since the interview results regarding fire management and effects were overall consistent, we did not attempt to analyze them quantitatively for the different categories. A display of age and socioeconomic status of the informants in relation to particular questions is, however, 
given in Results: Tables 1 and 2. Interview information relevant to fire management is summarized in the text together with selected verbatim excerpts.

\section{Fire observations and fire weather data collection}

During all 249 days spent in the heathlands during four different dry seasons, we recorded all observed fires and made notations of the date and time of day, current wind speed, and relative air humidity (measured by handheld instruments). We also visually estimated fire position (relative to known positions), slope, duration and spatial extent of the fire, and (when possible to observe) ignition sequence and approximate flame lengths.

To be able to link our field observations of heathland fire with fire weather, we calculated daily index values using the Canadian Fire Danger Rating System (Stocks et al. 1989). It has proved to be a reliable tool for scaling fire danger and potential fire behavior in various fuel types in different biomes, e.g., in Mediterranean shrublands (Viegas et al. 1999), which are similar in fuel structure to the Bale heathlands. The system uses input of noon readings of temperature, relative humidity, and wind speed, plus daily precipitation to calculate a set of indices that represent fuel moisture content, fire rate of spread, and fire intensity on relative scales (disregarding fuel type). We concentrated on the Fire Weather Index (FWI), which is designed to scale to fire intensity, with values greater than $\sim 25$ considered extreme (Stocks et al. 1989).

Weather variables for index calculations were taken at two different locations (27 km apart) at $3500 \mathrm{~m}$. Precipitation was measured in rain gauges and recorded every day by local staff. Radiation-shielded climate loggers (Tinytag plus, Gemini data loggers) placed $50 \mathrm{~cm}$ above the soil surface collected data continuously between February 2006 and February 2008, from which we extracted solar noon readings of temperature and relative air humidity. We had no continuous reading of wind speed, but frequent wind measurements with a handheld anemometer during fire observations suggested that wind patterns were rather uniform during clear days. We therefore entered a standard daily wind speed of $3 \mathrm{~m} / \mathrm{s}$ for the index calculations. To test the hypothesis that fire occurrence is positively related to FWI, a Poisson regression was performed (R Development Core Team 2010).

\section{Vegetation age structure and Erica development}

Vegetation composition and age structure at the landscape level was estimated by line-intercept sampling in different parts of the heathland. Eight transects of $\sim 1-2 \mathrm{~km}$ each were sampled within a $33 \times 11 \mathrm{~km}$ area. Four transects were sampled in January-February 2007 and four were sampled in February 2008. Two of the 2007 transects were resampled in 2008 in order to quantify the extent of burning in vegetation in which height and age were previously recorded. The transects were laid out parallel to the contour lines. Along each transect, the distinct borders between Erica stands of different height (indicating difference in time since last fire) were positioned using GPS. In each stand, we visually estimated slope and the percentage area cover of grass/herb vegetation and the two different species of Erica. The height of the two Erica species was sampled by measuring five individuals of each species. Basal stem sections were collected (one per species; in total, 138 stem sections) for later age determination by counting growth rings under a stereomicroscope. In this area, wood growth in the Erica ceases during the dry period, which leads to the formation of annual rings, which allows for age determination. We confirmed this by sampling Erica stems from areas with a known burn date (fires we had ourselves seen burning) and by scarifying small sections of the cambium at intervals on older Erica stems, which we cut 28 months later and analyzed under a stereomicroscope. On recently burned areas (1- to 2-years-old), dead stems were also sampled to determine the age of the vegetation at the time of the fire to enable us to calculate average fire return intervals. Dead stems decompose rapidly, which limited this sampling to recent burns only.

The ring counts of live Erica shoots enabled us to determine the time since fire for each stand along the transect. The proportion of different age classes along each transect was calculated using the distances between GPS points that marked the stand borders (Abeyta and Franklin 1998). Since most fires were observed in January and February, we assigned all burns dated to a particular dry season to the second calendar year of that dry season (e.g., to 2001 for fires dated to the dry season 2000/2001). For the resampled transects (sampled both in the dry period 2006/2007 and 2007/2008), the proportion of new burns in 2008 per each age class (age at the time of fire) was divided by the proportion of that age class available at the start of the 2007/2008 dry season to obtain a "probability" of burning for each age class.

\section{RESULTS}

\section{Interviews}

\section{History of livelihoods and land management}

All old informants said that when they were young they lived from cattle only. The major change according to most (Table 1 ) is that today there are more people on the mountain, each family has fewer cows, and each cow gives less milk: "When we were children the numbers of cows were many and one person could get milk for two children from one cow...there was sufficient grazing land for our cattle and we got a good amount of milk and milk products...milking frequency could be almost two times per day. At that time we harvested enough amounts of milk and honey but not now...there is a big difference relative to that time because the population has increased."

The only real discrepancies between informants we had classified as wealthy and poor were in their perception of 
Table 1. The most important historical changes cited by the informants to have occurred during their lifetime, separated by age and wealth groups. ${ }^{\dagger}$

\begin{tabular}{|c|c|c|c|c|c|c|c|c|}
\hline \multirow{2}{*}{$\begin{array}{l}\text { Age group } \\
\text { Wealth group } \\
\text { Number of informants }\end{array}$} & \multirow{2}{*}{$\begin{array}{l}\text { Young } \\
\text { poor } \\
2\end{array}$} & \multicolumn{3}{|c|}{ Middle } & \multicolumn{3}{|c|}{ Old } & \multirow[b]{2}{*}{$\begin{array}{l}\text { Tot. } \\
18 \\
\end{array}$} \\
\hline & & $\begin{array}{l}\text { poor } \\
3 \\
\end{array}$ & $\begin{array}{l}\text { mid. } \\
3\end{array}$ & $\begin{array}{l}\text { rich } \\
1 \\
\end{array}$ & $\begin{array}{l}\text { poor } \\
2 \\
\end{array}$ & $\begin{array}{l}\text { mid. } \\
3\end{array}$ & $\begin{array}{l}\text { rich } \\
4\end{array}$ & \\
\hline \multicolumn{9}{|l|}{ Historical change: } \\
\hline Reduced pasture/milk production per cow & $1(1)$ & 2 & 2 & & 2 & $1(1)$ & $3(1)$ & $11(3)$ \\
\hline Decrease in number of cattle per family & & & $2(2)$ & & $1(1)$ & 2 & 2 & $7(3)$ \\
\hline Increase in population density & & $2(1)$ & 2 & & & 1 & $1(1)$ & $6(2)$ \\
\hline Cessation of seasonal migration of cattle & & & 3 & & 1 & 1 & 1 & 6 \\
\hline Decline of forest cover below the tree line & & $1(1)$ & $2(1)$ & 1 & & & 2 & $6(2)$ \\
\hline Decreased rainfall & & & & $1(1)$ & & $1(1)$ & $2(1)$ & $4(3)$ \\
\hline Arrival of agriculture/barley (at lower elevations) & & & & & & $1(1)$ & $2(1)$ & $3(2)$ \\
\hline Fencing of grazing land in the forest & 1 & 1 & 1 & & & & & 3 \\
\hline Cessation of the landlord system & & & & & $1(1)$ & & & $1(1)$ \\
\hline Increased peace and stability & & $1(1)$ & & & & & & $1(1)$ \\
\hline Increased education levels & 1 & & & & & & & 1 \\
\hline Decrease in honey production & & 1 & & & & & & 1 \\
\hline Decrease in numbers of hyena/leopards & & & 1 & & & & & 1 \\
\hline Decrease in mountain nyala ${ }^{\S}$ & & & & & & 1 & & 1 \\
\hline No difference & $1(1)$ & & & & & & & $1(1)$ \\
\hline
\end{tabular}

${ }^{\dagger}$ Each informant spontaneously mentioned 2-5 different factors. For each factor, the number of informants who stated this first (indicating its importance) is given in brackets. The total number of informants who mentioned each factor is given in the last column.

The age groups are Young (20 to 29 years), Middle-aged (30 to 49 years), and Old (50 to 90 years).

${ }^{\S}$ Tragelaphus buxtoni, a large antelope

historical change (Table 1). The wealthier answered that life is more difficult today and that they have fewer cattle per family than when they were young: "When I was a child my family had about 100 cows and they grazed the whole mountain." Some of the poor stated that life is better today, despite the population increase, as one informant expressed: "When I was a child the land was owned by the landlord and now everybody is the owner of the land. The landlords allowed us to have cattle if we could pay for the land. The landlord owned more cattle than other people. Today we pay tax to the agricultural office but the payment is much less than what we paid to the landlord. Therefore, life is better now."

All old informants claimed that the heathlands have a long history of burning: "When I was a child the sato (the Oromo word for Erica) on the mountain looked the same as today, some was long and some was short because of fire...my grandfather knew how to burn sato." Fires in the Erica belt were considered a purely anthropogenic phenomenon; none of the informants had ever heard of lightning igniting heathland fires. The spontaneous comments to this question were as follows: "The lightning is always followed by rain," "The sato is too short to be hit by lightning," and "The lightning only hits tall trees in the forest, and burns that individual tree only."

\section{Rationale for fire use}

When asked about the reasons for burning the heathlands, all informants listed the same three reasons (Table 2), and most mentioned them in the same order: (1) to improve pasture quality, (2) to eradicate a toxic caterpillar (called "bokata" in the Oromo language) that makes the cattle sick, and (3) to remove hiding places for wild animals. When shown a photo of a $2.5 \mathrm{~m}$ tall Erica scrub and asked whether it is good pasture, one old woman said, "The old sato is very bad for the cows because they cannot reach the green shoots and because there is no grass under it. Also, there is bokata that makes the cows sick...and the hyena may hide in the tall bush."

All informants explained that recently burnt heathland (1- to $\sim 3$-years-old) (Fig. 1) is preferred by the cattle because it contains more grass, herbs, and young Erica shoots (Table 3 ). Most claimed that the grass/herb vegetation between Erica bushes was most important for cattle nutrition, but one old woman explained that "the grass is good for grazing during the rainy season but the sato is more important for the cows during the dry season, when the grass is dry," stressing that the evergreen Erica has increasing forage value during drought periods. We were also told that during the exceptionally long drought in the 2007/08 dry period (that lasted until May 2008), the families herding their cattle in the heathlands lost fewer cows to starvation than did families at lower elevations who were utilizing only forest pasture or the grassland on the plain 
Table 2. Stated reasons ${ }^{\dagger}$ for burning, separated by age and wealth groups.

\begin{tabular}{|c|c|c|c|c|c|c|c|c|}
\hline \multirow{3}{*}{$\begin{array}{l}\text { Age group } \\
\text { Wealth group } \\
\text { Number of informants }\end{array}$} & \multirow{3}{*}{$\begin{array}{l}\text { Young } \\
\text { poor } \\
2\end{array}$} & \multicolumn{3}{|c|}{ Middle } & \multicolumn{3}{|c|}{ Old } & \multirow{3}{*}{$\begin{array}{l}\text { Tot. } \\
18\end{array}$} \\
\hline & & poor & mid. & rich & poor & mid. & rich & \\
\hline & & 3 & 3 & 1 & 2 & 3 & 4 & \\
\hline \multicolumn{9}{|l|}{ Reasons for burning: } \\
\hline To improve pasture quality & $2(2)$ & $2(2)$ & $3(3)$ & $1(1)$ & $2(2)$ & $2(1)$ & $4(4)$ & $16(15)$ \\
\hline To get rid of a stinging caterpillar & 1 & $3(1)$ & 3 & 1 & 2 & $3(1)$ & 4 & $17(2)$ \\
\hline To get rid of hiding places for hyena/leopard & 2 & 2 & 3 & 1 & 2 & $2(1)$ & 4 & $16(1)$ \\
\hline To facilitate cattle movement & 1 & & & & & & & 1 \\
\hline
\end{tabular}

(below $2700 \mathrm{~m}$ elevation). The grass/herb lawn found between the Erica shrubs in the young stages consists, on average, of $50 \%$ grass species and $50 \%$ herb species (unpublished data). During the in-field interviews, we were informed that the cattle prefer the Trifolium spp., Thymus schimperi, and grass species, especially the grass species regenerating from seeds after deeper burns. The alpine rosette herb Haplocarpha rueppellii is common in the lawn and was said to be bad for the cows. When the canopy closes in older stages, the grasses and herbs are replaced by a moss layer beneath the shrubs (unpublished data), which according to one informant is "useless for the cattle but good for fire" (Table 3).

As for predators capable for slaying cattle, the most common were said to be spotted hyenas, but there are also leopards, and three of the old informants told us that stray lions have been seen and killed in the heathland in the past. Burning the heathland was stated to limit hiding places for predators and to facilitate the hunt of them. Hyenas were said not to attack cattle in the short vegetation (Table 3), except during foggy weather. The large predators have a central role in the traditional culture: "We have a celebration every year when we give the lion food...and no one insults the lion or hyena by calling his name because then he is believed to attack your cows."

Statements about the toxic caterpillar were highly uniform. It was said to be associated with older, flowering Erica (Table 3). "Bokata causes a skin rash on the cows and they become 'dry' and the milk production declines...it may eventually lead to their death." On a few occasions when riding through the area, guides pointed towards bokata occurrences, always in tall ( $2 \mathrm{~m})$ Erica. During one of the in-field interviews, we obtained specimens of the bokata. It was later identified as a caterpillar with urticating (i.e., stinging) setae, and it belonged to one of the families Lasiocampidae, Notodontidae, or Lymantriidae (Andrea Battisti, personal communication).
Assessments of vegetation as fuel, burning techniques, timing of fires

Time since fire was said to affect both flammability and grazing value (Table 3 ). One- to 3 -year old Erica vegetation was said to be very good pasture and impossible to burn. According to the informants, the lower age limit for the vegetation to be burnable lies around six years of age, depending on browsing pressure. But they also stated that 4to 5-year-old vegetation is possible to burn if it is very dense, if the slope is steep, or if the wind is strong. For those photos in which the vegetation was identified as "burnable", the informants also claimed that it "should" burn. Erica scrub that was $1.5-2 \mathrm{~m}$ tall was said to be very easily burnt (Table 3 ). According to most informants, $4 \mathrm{~m}$ tall Erica is more difficult to burn than $2 \mathrm{~m}$ tall Erica since "it is overgrown, because the branches are too far from the ground," or "there is no fuel under it." For a good result, the vegetation should be "tall enough to achieve a homogenous burn with clean borders and no remnant unburnt patches inside." One old man gave us a rule of thumb regarding Erica heights: "Sato up to the knees is good forage, from the waist it is burnable, and when above the head it should already have been burnt." Two other old men gave us distinct terms used to indicate the flammability of the vegetation: "sijja sato" refers to burnable Erica, and "qinchirae sato" is the term used for unburnable Erica.

When we showed different photos of borders between burnt and unburnt vegetation, the informants gave a variety of suggestions why the fire had stopped, such as "wind shift," "rain," or "the sato was too short to burn." Upon a direct question, all agreed that areas with short Erica (i.e., recent burns) are used as firebreaks to be able to control the size of a fire since fire cannot travel in the short vegetation (Fig. 2). However, many of the informants stated that the fire can jump more than $10 \mathrm{~m}$ if the wind is strong, and that sparks can ignite tall vegetation even farther away. 
Table 3. Vegetation status and summary of interview results in relation to Erica post-fire age.

\begin{tabular}{|c|c|c|c|c|c|c|c|}
\hline \multicolumn{3}{|c|}{ Vegetation data } & \multicolumn{5}{|c|}{ Summary of interview answers } \\
\hline Erica age (years) & $\begin{array}{c}\text { Erica trimera } \\
\text { average } \\
\text { height }^{\dagger} \\
(\mathrm{m})\end{array}$ & $\begin{array}{c}\text { Erica canopy } \\
\text { cover }^{\dagger} \\
(\%)\end{array}$ & Pasture quality & Bokata risk & Predator $^{\S}$ risk & Fire potential & Should be burnt \\
\hline 3 & 0.4 & 40 & best & none & low & none & no \\
\hline 6 & 0.7 & 60 & good & none & low & conditional & no/yes \\
\hline 15 & 1.6 & 90 & poor & high & high & high & yes \\
\hline 30 & 4.0 & 90 & very poor & high & high & decreasing & yes \\
\hline old forest & 11.0 & 90 & poor & none & $\mathrm{n} / \mathrm{a}$ & no & no \\
\hline
\end{tabular}

${ }^{\dagger}$ Erica height and canopy cover in relation to age refer to the upper limit for each class and are taken from the vegetation survey (Fig. 10) and unpublished data for older stages.

Bokata is the local name for the stinging moth caterpillar.

${ }^{\S}$ Large predators: hyena, leopard, and lion

I Can burn only with strong wind or steep slope

Fig. 2. Photographs of the same heathland valley side taken nearly two years apart, in the dry period 2006 and 2008 . The black areas in the 2006 photo were newly burnt, and the border of one of those (a) has been highlighted with a white trace. The area below (b) was burnt in January 2008, and the fire stopped against the border of the then 2-year-old burn (a), only scorching the plants a few meters into the 2-yearold vegetation, seen as a brown fringe above the 2008 burn. This indicates an upslope wind during the burning, as is typical in the area. Likewise, the left-hand margin of the 2008 fire borders another 2006 burn. The length of the ringshaped burn (a) is approximately $80 \mathrm{~m}$.
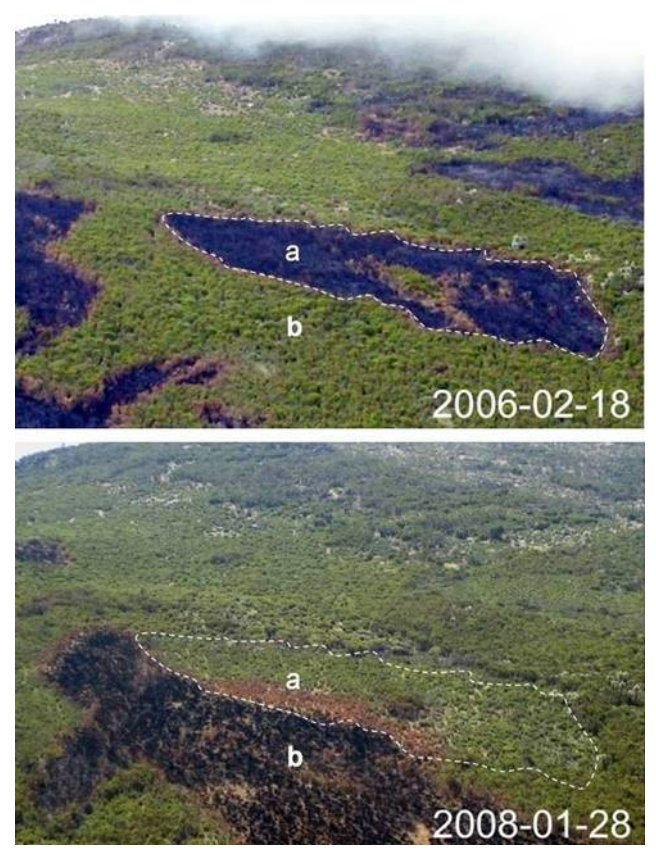

When shown photos of heathland dominated by the spiny alpine cushion plant Helichrysum citrispinum (Asteraceae) (called "tukka" in the Oromo language), the informants claimed that "this is not good pasture because the tukka is spiny, so the cows cannot reach the grass under it," and some spontaneously said, and the rest said when asked, that this land could be improved by fire, but "it is much more difficult to burn tukka than sato because the fire does not transfer between the plants...each tukka bush has to be ignited individually." This was confirmed by many observations we made of individual burnt Helichrysum plants. Only once did we see a whole patch of burnt Helichrysum/Erica vegetation. It had been burnt towards the end of the extreme drought in the spring of 2008 .

Erica was recognized as the prime fuel component in the heathlands, but grass was also mentioned regarding lower elevation fires. One old man detailed the consequences of relaxed grazing following an outbreak of cattle disease during the time of his grandfather (more than 100 years ago, most likely the Rinderpest outbreak in the 1890s): "The fire crossed the grass plain and went up in the forest from Dodola...this happened after all the cattle had died." When we asked about this cattle disease in the following interviews, five old informants mentioned the "Great Famine" following the cattle epizootic (locally called "madini"), and one old man gave us a local saying about the aftermath: "Namni tokee ta' a-Margi kokkee gayee," which translated means "people became scattered - the grass grew to their throats" (referring to the grass on the plain). Three old informants mentioned another outbreak of the epizootic in the 1970s, in which one of them lost 60 cows. He said the cattle death was followed by large grass fires on the plain, and he described how he participated in fighting them.

According to the informants, the burning season is equal to the dry period, and most claimed that the best month for 
burning is January, and that it takes about three weeks after the long rains stop (at the end of October) before the vegetation can burn. The wind normally blows upslope during the day and downhill in the late afternoon, and all informants preferred the uphill wind for burning (Fig. 3): "The best time to burn is at midday when the bush is dry and the wind starts blowing uphill." When we asked specifically which part of the vegetation should be dry, they answered that it is important that the moss and the litter under the bush is dry. When we asked if it was possible to burn during nighttime, we got different answers: "Yes, the wind is stronger during nighttime" or "Yes it is possible, but not practiced because it is often too cold."

Fig. 3. Heathland fires on February 4, 2008 at 1210 hours on a northeast-facing slope, ignited at multiple points along a straight line and allowed to burn uphill, supported both by the slope effect and the noon uphill wind. Note the other fires on the mountain in the background to the left.

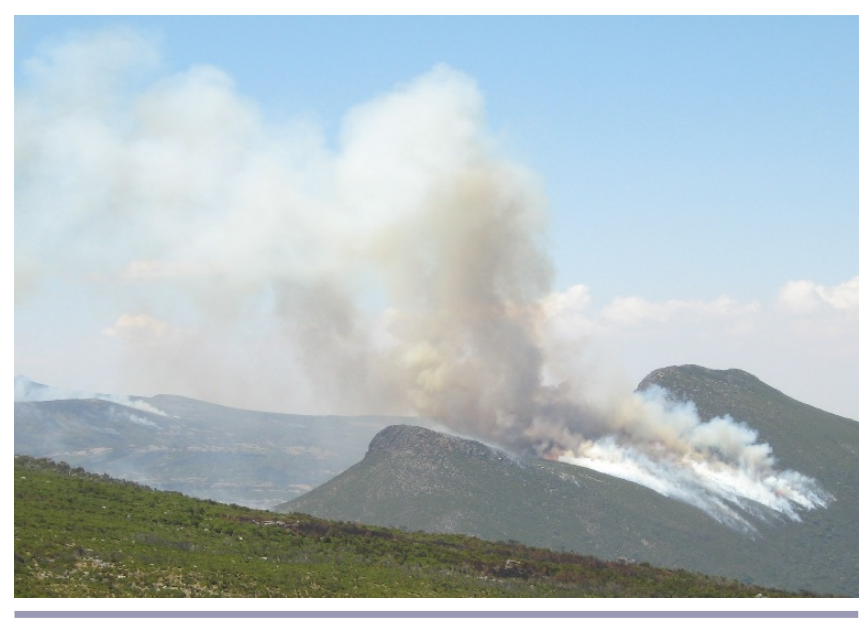

Fires are ignited with a "shewa" (a torch of dry Erica shoots, Fig. 4a) at many separate points in a straight line along the lower side of the intended burn area, which allows the fire to go uphill and with the wind. This was confirmed by our test burn and field observations of ignition patterns (Fig. 3). The informants told us about different containers for transport of glowing embers (also called "shewa" or "konshora"), which are made out of bamboo splints, tree bark, or the hollow inflorescence stem of the giant lobelia (Lobelia rhynchopetalum) (Fig. 4b). These are traditionally used for carrying fire (e.g., during honey collection from wild bees) and for igniting heathland fires. Most informants claimed that only men and children perform the burning, and never women, but two old women claimed that sometimes women also participate. One to three people was said to be enough to manage a burn. Three informants said that children often do the burning today since the men are afraid of prosecution.
Fig. 4. (A) A torch, "shewa," for ignition, made of tightly bundled dry Erica shoots tied together by a Thymus schimperii stem. Note that it is the compact end of the bundle that is burning. (B) Shewa for transporting fire and for ignition, made out of a hollow giant lobelia (Lobelia rhynchopetalum) inflorescence stem filled by glowing embers pushed forward to activate it as a torch.

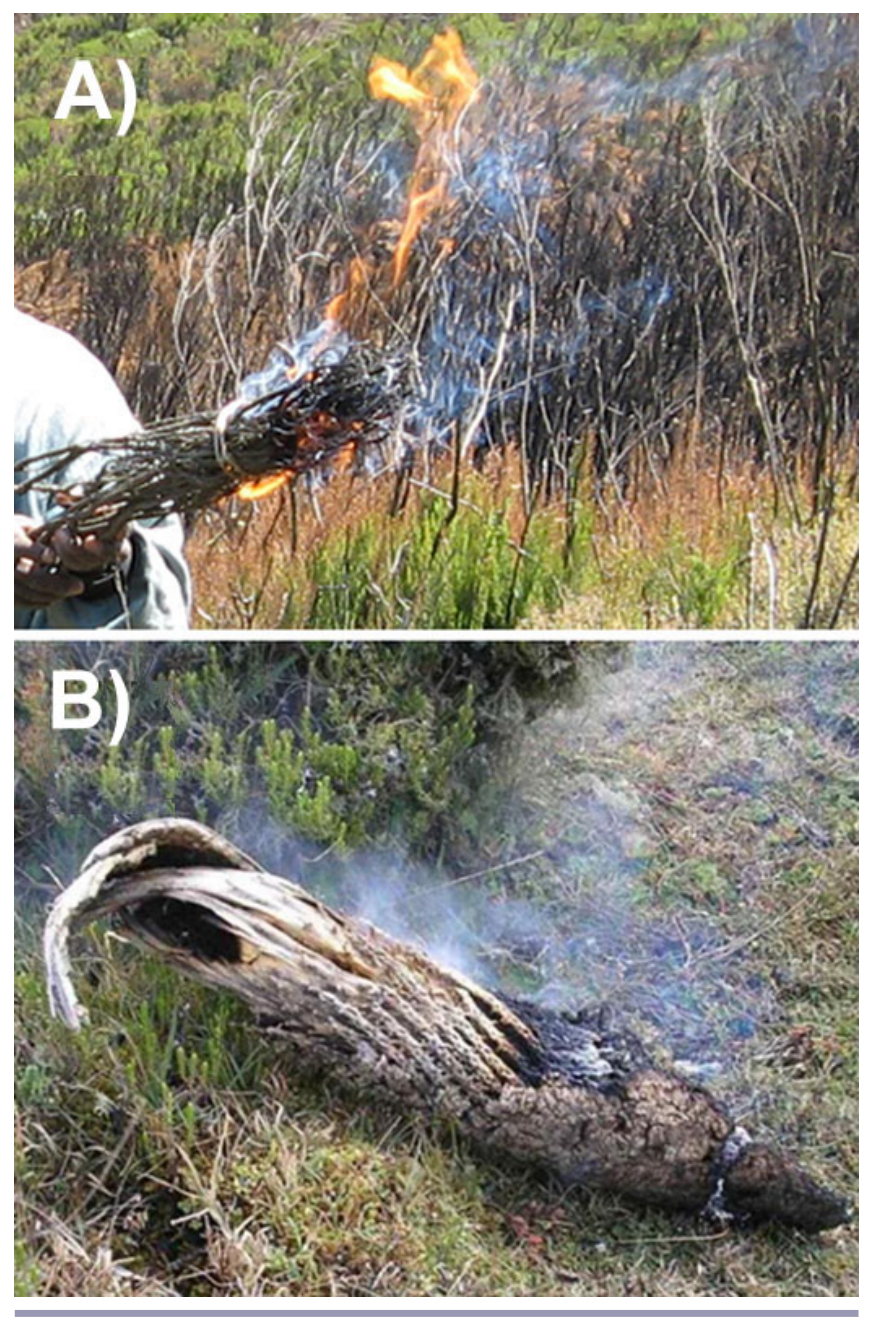

Most informants said they preferred large-sized uniform burns rather than many small burns because large burns require less effort per unit area burnt. But four of the old informants argued that it is important to have many small burns of different ages in order to always have good pasture "since it takes more than a year before a new burn gives good pasture."

When asked about possible risks when burning tall Erica scrub, most informants ensured us that "there is no danger because the cows and children see the smoke and they run away...sometimes we may make a signal to warn the children before firing." Only two old men had heard about any fire 
accidents. In one case "five cows got trapped between the fire and a stony area because of a sudden wind shift, and they died." Another old man told us "one man got fire in his clothes...he did not die, but he got wounds, and there was no hospital...he was given milk and meat and recovered."

When shown photos of burning Erica with white or black smoke, most informants claimed that "the white smoke shows that the sato is too wet to burn well,"..."it is on its way to stop" or "the fire with black smoke is a guba gari (good fire in the Oromo language) and it results in better pasture quality," or "the one which cleans all sato is a guba gari." None of the informants detailed why the pasture would be better after a good fire, but during the in-field interviews informants claimed that a good fire reduces the size of the remaining stumps that limit the cattle access to the fresh shoots, and that there is more new grass: "A good fire gives better pasture... but if the fire burns too deep in the soil, the regeneration may be delayed...but after some time the yield is very high compared to bad burns."

We asked why we sometimes observed cattle on the fresh black burns, and were told that they were attracted to the ash because it "tastes salty," and in one of the in-field interviews we were also shown fire-heated mineral soil that the cattle were said to lick for minerals.

\section{Legality}

All informants stated that burning of the heathland is illegal today, but they gave us very different dates as to when the burn ban was implemented: during the Deurge time (19741991), 1988, 2000, or 2007, or they said that they did not know when it became illegal. Most also claimed that they did not know the reason why burning is illegal, but two informants said "it is because the agricultural bureau thinks the fire may spread to the forest below...the forest cannot burn because there is no fuel on the ground." Only two informants (both in the same area) had heard of anyone going to prison for burning heathland. Four informants said that a special permission for burning could be obtained if they could prove that the bokata caterpillar was a serious problem for the cattle and if they could bring in specimens to the agricultural bureau, but only one informant had heard that such a burning permit had ever been issued. Another said "there is no point in asking, since it is illegal." All informants claimed that if burning ceased, after only a few years there would not be enough forage for the cattle.

\section{Fire observations and fire weather}

During our four dry seasons of field work we observed 192 separate heathland fires (16 in the 2004/2005 dry season, 36 in the 2005/2006 dry season, four in the 2006/2007 dry season, and 136 in the dry season 2007/2008). The FWI over the period 2006-2008 mirrored the annual cycle of dry and wet periods but was also highly variable during the dry period (Fig. 5), reflecting occasional episodes of precipitation. Fires were observed in December (12\%), January (45\%), and February (43\%). Most fires (83\%) occurred at FWI values greater than 25 (Fig. 6b), but the proportion of all measured days (from February 2006 to February 2008, including rainy seasons) with an FWI value greater than 25 was only $11 \%$ (Fig. 6a). The chance of observing a fire (expressed as number of fires per FWI class divided by the number of observation days per FWI class) increased progressively with increasing FWI (Fig. 6c). There was a statistically significant relationship between FWI and number of observed fires per day $(z=21.92, P<0.001)$.

Fig. 5. Calculated daily values of the Fire Weather Index (FWI) for the period February 11, 2006 to February 11, 2008 .

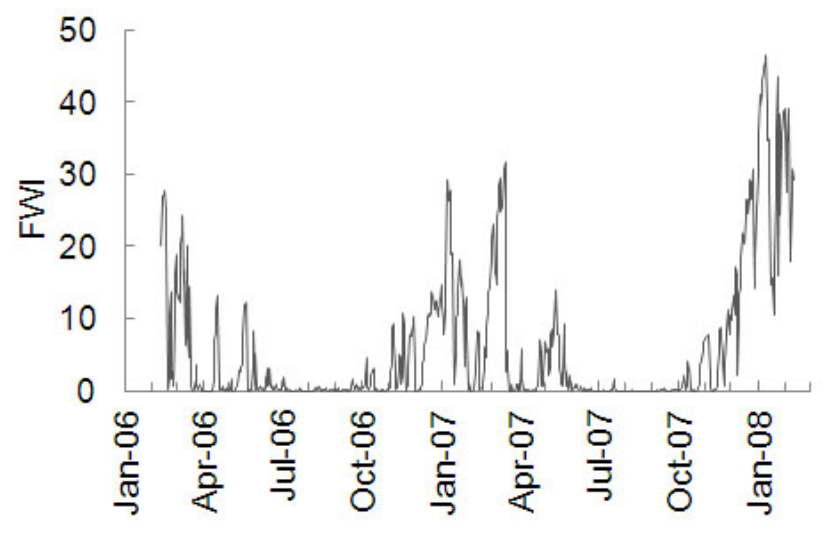

Fires were concentrated in the period of the day with the highest air temperature and the lowest relative air humidity (Fig. 7). Ninety-five percent of all fires were observed between 1000 and 1600 hours. Wind speed recorded for the observed fires ranged from 0 to $6 \mathrm{~m} / \mathrm{s}$ with an average of $2.5 \mathrm{~m} / \mathrm{s}$. There were occasional wind gusts up to $9 \mathrm{~m} / \mathrm{s}$. Flame lengths could be only roughly classified since the distance to the fires was often several hundred meters. Flame lengths were estimated to be in the range of 3-10 m. Sizes of the individual burns ranged from $\sim 0.5$ to 5 ha. In several cases, we observed successive burning of adjacent patches, and typically, fires burned until reaching recently burnt vegetation (Fig. 2).

Most of the observed fires had minor effects on the humus layer, and smoldering usually stopped in less than one hour. Only on rare occasions did we observe prolonged smoldering eating into decayed lignotubers. But in areas that burnt towards the end of the prolonged drought in early 2008, deep smoldering $(>10 \mathrm{~cm})$ into the humus layer was observed, as were a few fire-killed Erica lignotubers.

\section{Vegetation age structure and Erica development}

Along the sampled line transects there were no Erica stands older than 13 years, and there was a gradual decrease in area per age class towards the older age classes, reflecting the 
Fig. 6. (a) The proportion of days per Fire Weather Index (FWI) class. $\mathrm{x}$ denotes the relative proportion of all measured days, including the rainy season. The grey bars show the proportion of observation days for the dry season days only. (b) The number of observed fires per FWI class. (c) Fire occurrence per FWI class expressed as number of observed fires/number of observation days in each FWI class. The number on the FWI axis is the upper limit of each FWI class.
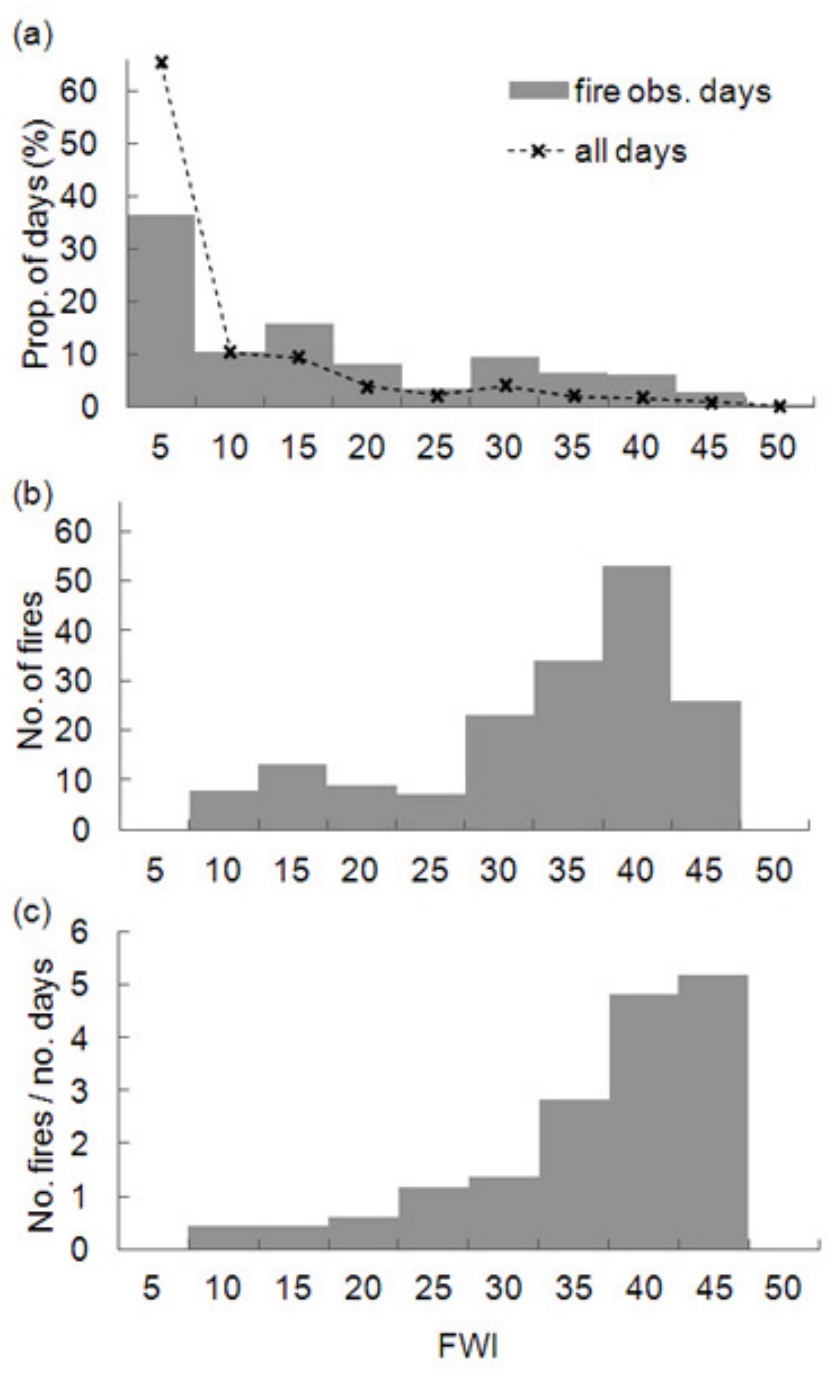

decreasing chance for a patch to have escaped re-burning with increasing time since fire (Fig. 8). Within this overall pattern there was a large variation in area burnt in different years. Relatively large areas burned during 2000 and 2005, whereas only tiny fractions burned in 2002 and 2007. Four of the transects were sampled in January and February 2007 and the rest were sampled in February 2008, so 2008 was underrepresented in the data. During a short visit to the area
Fig. 7. Temporal distribution of the observed heathland fires. The curves illustrate the average relative air humidity $(\mathrm{RH})$ and temperature $(\mathrm{T})$ for all days with at least one fire observation.

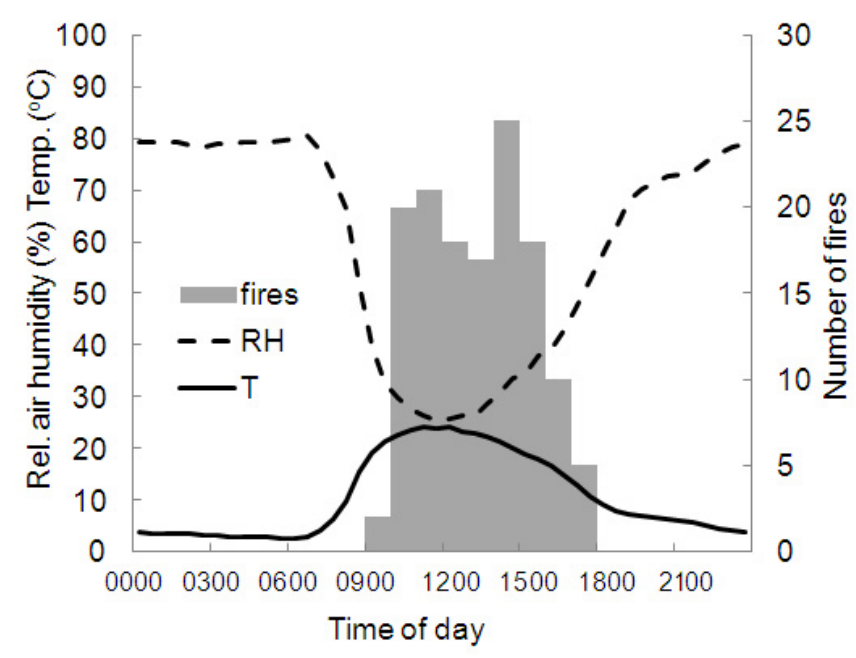

in November 2008 we noted that large areas had been burnt later than February 2008 during an exceptionally prolonged drought that lasted until the end of April (according to our precipitation records).

The age of fire-killed Erica stems (i.e., age at time of fire) that were sampled in recently burned areas averaged 10.2 years (S. E. 3.6; $n=29$ ), with a range from six to 19 years. For the two resampled transects, there were no stands that were below the age of five years when they burned in 2008 (Fig. 9), despite the fact that 1- to 4-year-old vegetation accounted for $42 \%$ of the area along the transects. For the older age classes $(>4$ years), on average, $23 \%$ had been burnt in 2008, and there was no clear increase with age of the vegetation (Fig. 9). The mean age (area-weighted) for the stands that burned in 2007/08 along these transects was 9.3 years, again suggesting a fire return interval of approximately 10 years.

The Erica scrub increased gradually in height and area cover with age (Fig. 10). On average, E. trimera reached $100 \mathrm{~cm}$ in 10 years. E. arborea was on average $40 \%$ taller than E. trimera, but since E. trimera was dominating in all transects (on average, $72 \%$ of the Erica bushes), height development is displayed for E. trimera only. The area cover of Erica bushes increased with time since fire. The canopy was more or less closed (branches of adjacent bushes touching each other) six to eight years after fire (Fig. 10b). 


\section{DISCUSSION}

The fire management system of the Bale Mountain heathlands, with its resulting vegetation structure, has evidently developed primarily out of the need to maintain good quality pasture for cattle. Cattle browsing height is limited to $\sim 1.5 \mathrm{~m}$ (Sanon et al. 2007), implying that the Erica start to grow out of the reach of cattle about 10 years after fire, which also corresponds to the average fire return interval (as indicated both by age of fire-killed stems and the resampled transects). Further, the informants claimed that the cattle prefer the "fresh" resprouting Erica shoots the first one to three years after fire, which is corroborated by slightly lower fiber content and higher protein content in the top shoots of 1- to 3-year old $E$. arborea and E. trimera compared to top shoots from 7- to 12year old bushes (Johansson et al. 2009). In a study of habitat use by cattle in this area (Gustafsson 2009), most feeding time was indeed spent in the age classes 1-3 years, which also had the largest area cover of grass/herb vegetation (including a large proportion of Trifolium spp.) providing high-quality forage. Still, some informants emphasized that the Erica shoots are equally important as the grass/herb component since the Erica species are evergreen and provide forage also during periods of extreme drought, when grasses and herbs cure.

Fig. 8. Relative area distribution of vegetation age classes from all transects from both sample years (2007 and 2008). Note that the relative area for 2008 burns is underrepresented since half of the data was collected in 2007. Some of the areas that burnt a long time ago have since burnt again; hence, the decrease in relative area with increasing age.

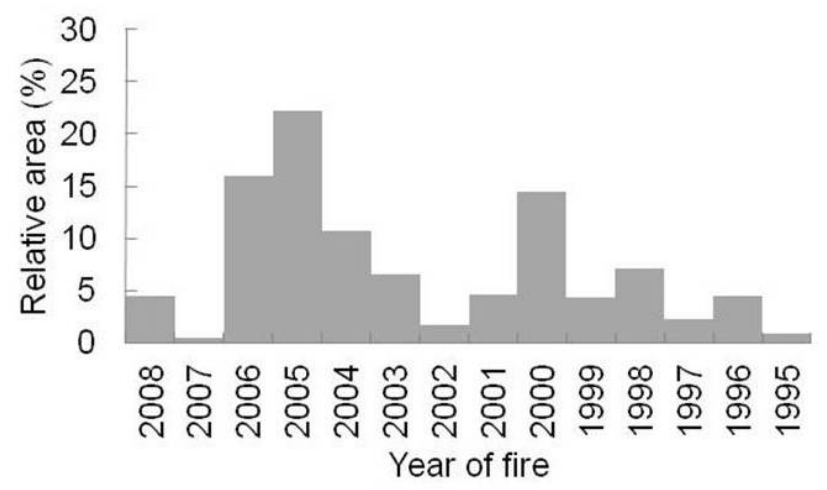

The other main reason to burn the heathland, to eradicate the toxic caterpillar, has not been reported earlier, and this shows the importance of using interviews to understand people's incentives for burning. Urticating setae of a similar kind from a number of moth species from around the world are known to cause respiratory and skin irritations in humans and animals (Battisti et al. 2011), which conforms to interview statements about bokata effects on cattle. Finally, burning removes hiding places for the large predators, mainly hyenas and leopards, which are serious threats to both humans and livestock (Atickem et al. 2010). Thus, three powerful arguments were given for short-interval burning as range management, none against. Despite the limited number of informants, their overall congruence suggests that we have uncovered the general views regarding proper use of fire to maintain productivity in these heathlands.

Our informants gave less specific statements about the preferred landscape structure and sizes of burns, probably because they have not experienced very large, landscapecovering fires. But such fires would be disastrous since, as some of the old informants pointed out, it takes at least one year before a new burn produces enough forage, so a landscape-covering fire would cause famine locally. In the past, the herders could move the cattle longer distances to new pastures, but today the lifestyle has become more sedentary and there is a need for stands of different age within the daily walking distance of the cattle herd, about $6 \mathrm{~km}$ (Gustafsson 2009).

In contrast to savanna systems, where fuel buildup is fast and the fire-created patch-mosaic is quite ephemeral, burnt areas in these heathlands act as firebreaks for several years. This makes the landscape patch structure more long-lasting but would also make it more difficult to reconstruct when lost. At the same time, fire would be expected to be even more important for maintaining pasture quality in this habitat, where relaxation of burning allows shrubland to revert into a low forest with little grazing value.

Fig. 9. Fire incidence in relation to age class for the two transects that were sampled both in 2007 and in 2008. Bars denote the proportion of the area in each age class that was burned between January 2007 and February 2008. x denotes the "available" area in each age class at the beginning of the dry season 2008 .

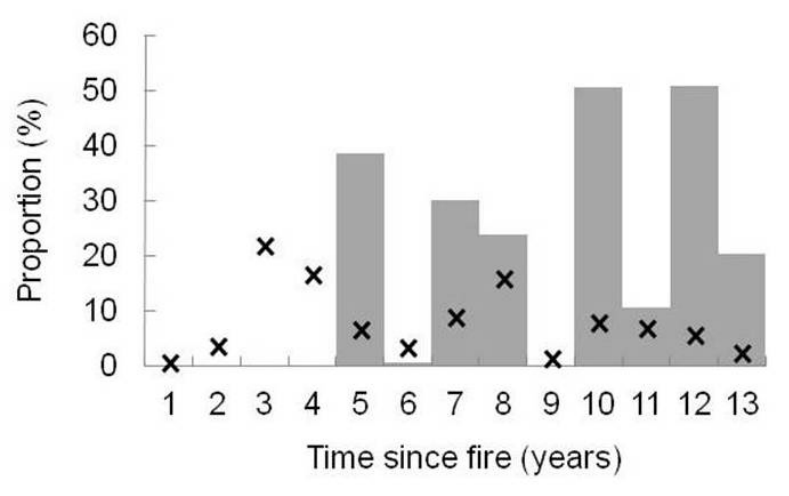


The present small-scale mosaic of stands of different ages is totally dependent on the fact that young burns act as firebreaks. The mountain landscape lacks other types of firebreaks, except some small rocky outcrops. Most streams are ephemeral and too narrow to stop a fire. According to the informants and to our field observations, 1- to 3-year-old vegetation cannot carry a fire, while 4- to 5-year old vegetation potentially can burn but only in extreme situations (steep slope, strong wind, or advanced drought). Six- to 10-year-old vegetation is easily burnt during favorable weather. It is possible that the observed fuel limitation is partially dependent on high grazing pressure since grass and herbs in early successional stages are cropped short (unpublished data). Relaxed grazing will likely result in a more continuous fuel bed in early succession, with taller grass/herb in-between the Erica, but it is not known if, and at what level of drought, the grass/herb vegetation would cure enough to carry fire. The potential role of grass fuels at lower elevations was mentioned in the interviews regarding the postRinderpest fire episode but would not be an issue under current grazing pressure.

The informants had a detailed perception of fire behavior and its governing factors, such as fuel structure, fuel moisture, wind, and slope. There are also several examples of how this knowledge was used in the fire management. Fuel was visually assessed with regard to horizontal as well as vertical continuity, and there was a good understanding of how this developed with time since fire. Ignition patterns were set to take advantage of both slope and wind. In total, this amounts to a substantial knowledge base among a large number of people and should be valuable for all future land management initiatives in the area. It is likely that this level of expertise is typical for any region with a long history of anthropogenic fire.

One reason for frequent tension between traditional fire management and state policies in different parts of the world is real land use conflicts, such as that between forestry and grazing (Moreira et al. 2001). In other cases, tension may be due to mutual distrust and lack of fire knowledge among government officials (Sletto 2009). If so, much of these issues could be solved through participatory land use planning. For example, the fear stated by officials in Bale that heathland fires would spread to the tall forest below is a case in point. It was never observed during the study period and is unlikely to happen due to lack of suitable fuel (unpublished data).

The heathland burning in the Bale Mountains is heavily biased towards days with very high fire weather indices (Fig. 6a), which is surprising given that ericaceous live fuels typically are flammable as soon as their surface is dry (Davies et al. 2009). The likely reason is that the moss/litter under the Erica has to be sufficiently dry to support the fire, as was pointed out by the informants. Since the topsoil has a high organic content (Yimer et al. 2006), deep smoldering is also possible
(Frandsen 1987). Nevertheless, most fires seem to burn off only the surface fuels, suggesting that the humus layer is usually too moist to smolder. However, the occasional death of Erica lignotubers we observed after fires that had burnt towards the end of the prolonged drought in 2008 shows that there is indeed a potential for type conversion towards grassland since seed recolonization of Erica spp. is very poor (Wesche et al. 2008).

Fig. 10. (a) Height of Erica trimera in relation to time since fire. (b) Canopy cover of Erica spp. (both E. trimera and E. arborea) in relation to time since fire.
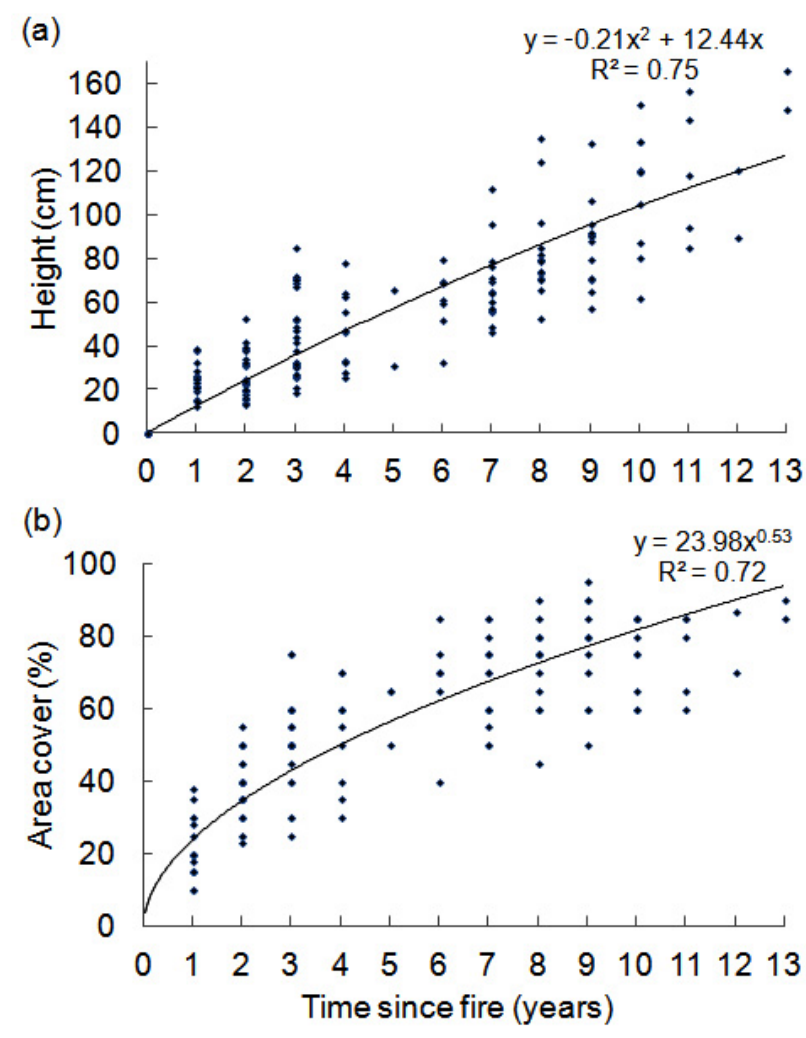

It is not known for how long these heathlands have been subjected to anthropogenic fire, but it is likely that they have been burnt on short rotation as long as people have kept cattle there. The scant historical information suggests that pastoralist people have been utilizing the Bale Mountains for many hundreds of years (Haberland 1963). Early visitors report on a moorland of short fire-disturbed Erica scrub (Bourg des Bozas 1906, Brown 1969). The presence of very large Erica lignotubers is further evidence of a long history of burning since the lignotubers increase radially quite slowly: for $E$. arborea, a yearly radial growth rate of only $2 \mathrm{~mm}$ has been reported (Garland and Marion 1960). In the Bale Mountains, E. trimera lignotubers are often more than $1.5 \mathrm{~m}$ in diameter and are likely to be several hundred years old. Possibly, natural 
fires could also have fostered the development of these large lignotubers, but lightning fires were unheard of among the informants. Lighting is frequent towards the late dry period (personal observation), and ignitions would be expected when the humus is dry (Latham and Williams 2001). Given the massive amount of anthropogenic fire, lightning ignitions are likely to get little attention, but their complete absence from the collective memory suggests they are indeed very rare.

\section{CONCLUSION}

There is today a dramatic discrepancy between official policy and current fire management in the area. The average fire return interval is in the order of 10 years despite the fact that burning is illegal. If instead the official blanket ban on fire was respected, large problems would develop within only a few years. First, the grazing potential of the area would decline severely. Second, a potential for large-scale high-intensity wildfire would gradually emerge as fuels build up and the present firebreaks disappear. On the other hand, it is not known if the current regime of fire and grazing is truly sustainable in the long term. The system is partly self-regulating since the relatively slow fuel buildup puts a lower limit on fire return intervals and the Erica lignotubers provide efficient regrowth, but grazing pressure today is likely to be at unprecedented levels (Vial et al. 2010). Also, burning during extreme drought may pose a risk of deep smoldering killing lignotubers, and this may be further augmented by a changing climate with increasingly severe droughts (Hulme et al. 2001). Given the highly flammable nature of the Erica scrub, and the immediate interests of the pastoralists, any attempt to modify current land management is likely to be successful only if these people and their traditional fire knowledge are incorporated into the process.

Responses to this article can be read online at: http://www.ecologyandsociety.org/vol17/iss3/art19/ responses/

\section{Acknowledgments:}

We thank our informants who freely shared their knowledge and our field interpreters and assistants Ayano Abraham and Shebru Marefu and translators Getachew Birhanu and Berhanu Terefe. We thank the Agricultural \& Rural Development Bureau of the Regional Government of Oromia for the research permit. Professor Andrea Battisti at the University of Padova generously identified the moth caterpillar, and Dr Melaku Bekele provided information regarding Ethiopian law. Bright Kumordzi assisted with the statistical analysis. The study was funded by The Swedish International Development Cooperation Agency.

\section{LITERATURE CITED}

Abeyta, A. M., and J. Franklin. 1998. The accuracy of vegetation stand boundaries derived from image segmentation in a desert environment. Photogrammetric Engineering and Remote Sensing 64:59-66.

Angassa, A., and G. Oba. 2008. Herder perceptions on impacts of range enclosures, crop farming, fire ban and bush encroachment on the rangelands of Borana, southern Ethiopia. Human Ecology 36:201-215. http://dx.doi.org/10.1007/s1074 5-007-9156-Z

Anonymous. 2012. Central Statistical Agency of Ethiopia. Addis Ababa, Ethiopia. [online] URL: http://www.csa.gov.et/

Atickem, A., S. Williams, A. Bekele, and S. Thirgood. 2010. Livestock predation in the Bale Mountains, Ethiopia. African Journal of Ecology 48:1076-1082. http://dx.doi.org/10.1111/ j.1365-2028.2010.01214.x

Battisti, A., G. Holm, B. Fagrell, and S. Larsson. 2011. Urticating hairs in arthropods: their nature and medical significance. Pages 203-220 in M. R. Berenbaum, R. T. Carde, and G. E. Robinson, editors. Annual Review of Entomology, Vol 56. Annual Reviews, Palo Alto, California, USA. http://d x.doi.org/10.1146/annurev-ento-120709-144844

Berkes, F., J. Colding, and C. Folke. 2000. Rediscovery of traditional ecological knowledge as adaptive management. Ecological Applications 10:1251-1262. http://dx.doi.org/10.1 890/1051-0761(2000)010[1251:ROTEKA]2.0.CO;2

Bird, R. B., D. W. Bird, B. F. Codding, C. H. Parker, and J. H. Jones. 2008. The "fire stick farming" hypothesis: Australian Aboriginal foraging strategies, biodiversity, and anthropogenic fire mosaics. Proceedings of the National Academy of Sciences of the United States of America 105:14796-14801. http://dx.doi.org/10.1073/pnas.0804757105

Bourg des Bozas, V. d. 1906. De la mer Rouge à l'Atlantique à travers l'Afrique tropicale (1906 Octobre 1900-Mai 1903). F. R. de Rudeval, Paris, France.

Bowman, D. 1998. Tansley Review No. 101-The impact of Aboriginal landscape burning on the Australian biota. New Phytologist 140:385-410.

Bowman, D. M. J. S., J. K. Balch, P. Artaxo, W. J. Bond, J. M. Carlson, M. A. Cochrane, C. M. D'Antonio, R. S. DeFries, J. C. Doyle, S. P. Harrison, F. H. Johnston, J. E. Keeley, M. A. Krawchuk, C. A. Kull, J. B. Marston, M. A. Moritz, I. C. Prentice, C. I. Roos, A. C. Scott, T. W. Swetnam, G. R. v. d. Werf, and S. J. Pyne. 2009. Fire in the Earth system. Science (Washington) 324:481-484. http://dx.doi.org/10.1126/scienc e.1163886 
Brown, L. H. 1969. Observations on the status, habitat and behaviour of the mountain nyala Tragelaphus buxtoni in Ethiopia. Mammalia 33:545-597. http://dx.doi.org/10.1515/m amm.1969.33.4.545

Butz, R. J. 2009. Traditional fire management: historical fire regimes and land use change in pastoral East Africa. International Journal of Wildland Fire 18:442-450. http://dx. doi.org/10.1071/WF07067

Collier, J., and M. Collier. 1986. Visual anthropology: photography as a research method. Revised and expanded edition. University of New Mexico Press, Albuquerque, New Mexico.

Davies, G. M., C. J. Legg, A. A. Smith, and A. J. MacDonald. 2009. Rate of spread of fires in Calluna vulgaris-dominated moorlands. Journal of Applied Ecology 46:1054-1063. http:/ /dx.doi.org/10.1111/j.1365-2664.2009.01681.x

Dimitrakopoulos, A. P., and P. I. Panov. 2001. Pyric properties of some dominant Mediterranean vegetation species. International Journal of Wildland Fire 10:23-27. http://dx.doi. org/10.1071/WF01003

Eriksen, C. 2007. Why do they burn the 'bush'? Fire, rural livelihoods, and conservation in Zambia. Geographical Journal 173:242-256. http://dx.doi.org/10.1111/j.1475-4959. 2007.00239.x

Frandsen, W. H. 1987. The influence of moisture and mineral soil on the combustion limits of smoldering forest duff. Canadian Journal of Forest Research 17:1540-1544. http://dx .doi.org/10.1139/x87-236

Garland, H., and L. Marion. 1960. California Manzanita for smoking pipes. Technical Notes. California Forest and Range Experiment Station:10.

Gashaw, M., M. Fetene, Y. Assefa, Z. Woldu, and E. Beck. 2009. Diversity of afroalpine vegetation and ecology of treeline species in the Bale Mountains, Ethiopia, and the influence of fire. Pages 15-38 in E. M. Spehn, editor. Land use change and mountain biodiversity. CRC Press. http://dx.d oi.org/10.1201/9781420002874.ch2

Granström, A., and M. Niklasson. 2008. Potentials and limitations for human control over historic fire regimes in the boreal forest. Philosophical Transactions of the Royal Society B-Biological Sciences 363:2353-2358. http://dx.doi.org/10.1 098/rstb.2007.2205

Gustafsson, J. 2009. Habitat and plant selection of livestock in a fire-managed Afro-alpine heathland in Ethiopia. Thesis, Swedish University of Agricultural Sciences, Uppsala, Sweden.

Haberland, E. 1963. Galla Süd-Äthiopiens. W. Kohlhammer Verlag, Stuttgart, Germany.
Hough, J. L. 1993. Why burn the bush? Social approaches to bush-fire management in West African national parks. Biological Conservation 65:23-28. http://dx.doi.org/10.1016 10006-3207(93)90192-4

Hulme, M., R. Doherty, T. Ngara, M. New, and D. Lister. 2001. African climate change: 1900-2100. Climate Research 17:145-168. http://dx.doi.org/10.3354/cr017145

Huntingford, G. W. B. 1955. The Galla of Ethiopia; the Kingdoms of Kafa and Janjero, London, UK.

Huntington, H. P. 2000. Using traditional ecological knowledge in science: methods and applications. Ecological Applications 10:1270-1274. http://dx.doi.org/10.1890/1051-0761 (2000)010[1270:UTEKIS]2.0.CO;2

Johansson, M., T. Rooke, M. Fetene, and A. Granström. 2009. Browser selectivity alters post-fire competition between Erica arborea and E. trimera in the sub-alpine heathlands of Ethiopia. Plant Ecology 207:149-160. http://dx.doi.org/10.10 07/s11258-009-9661-9

Keeley, J. E. 2002. Native American impacts on fire regimes of the California coastal ranges. Journal of Biogeography 29:303-320. http://dx.doi.org/10.1046/j.1365-2699.2002.00676. $\underline{\mathrm{X}}$

Kepe, T., and I. Scoones. 1999. Creating grasslands: social institutions and environmental change in Mkambati area, South Africa. Human Ecology 27:29-53. http://dx.doi.org/10 $.1023 / \mathrm{A}: 1018753216660$

Kull, C. A. 2004. Isle of fire-the political ecology of landscape burning in Madagascar. University of Chicago Press, Chicago, USA, London, UK.

Laris, P. 2002. Burning the seasonal mosaic: preventative burning strategies in the wooded savanna of southern Mali. Human Ecology 30:155-186. http://dx.doi.org/10.1023/A:10 15685529180

Laris, P., and D. A. Wardell. 2006. Good, bad or 'necessary evil'? Reinterpreting the colonial burning experiments in the savanna landscapes of West Africa. Geographical Journal 172:271-290. http://dx.doi.org/10.1111/j.1475-4959.2006.00215. $\underline{\mathrm{x}}$

Latham, D., and E. Williams. 2001. Lightning and forest fire. Pages 375-418 in E. Johnson and K. Miyanishi, editors. Forest fires-behavior and ecological effects. Academic Press, San Francisco, USA. http://dx.doi.org/10.1016/B978-012386660$\underline{8 / 50013-1}$

Lewis, H. T. 1989. A parable of fire: hunter-gatherers in Canada and Australia. Pages 11-19 in R. E. Johannes, editor. Traditional ecological knowledge: a collection of essays. International Union for Conservation of Nature and Natural Resources, Gland, Switzerland. 
Lewis, H. T., and T. A. Ferguson. 1988. Yards, corridors, and mosaics-how to burn a boreal forest. Human Ecology 16:5777. http://dx.doi.org/10.1007/BF01262026

Mbow, C., T. T. Nielsen, and K. Rasmussen. 2000. Savanna fires in east-central Senegal: distribution patterns, resource management and perceptions. Human Ecology 28:561-583. http://dx.doi.org/10.1023/A:1026487730947

Métailié, J. P. 2006. Mountain landscape, pastoral management and traditional practices in the northern Pyrenees (France). Pages 108-124 in M. Agnoletti, editor. The conservation of cultural landscapes. CAB International, Wallingford, UK.

Miehe, G., and S. Miehe. 1994. Ericaceous forests and heathlands in the Bale mountains of South Ethiopia: ecology and man's impact. Stiftung Walderhaltung in Africa, Hamburg, Germany.

Moreira, F., F. C. Rego, and P. G. Ferreira. 2001. Temporal (1958-1995) pattern of change in a cultural landscape of northwestern Portugal: implications for fire occurrence. Landscape Ecology 16:557-567. http://dx.doi.org/10.1023/A $\underline{1013130528470}$

Pausas, J. G., and J. E. Keeley. 2009. A burning story: the role of fire in the history of life. Bioscience 59:593-601. http://dx. doi.org/10.1525/bio.2009.59.7.10

Pereira, J. M. C., N. M. S. Sequeira, and J. M. B. Carreiras. 1995. Structural-properties and dimensional relations of some Mediterranean shrub fuels. International Journal of Wildland Fire 5:35-42. http://dx.doi.org/10.1071/WF9950035

R Development Core Team. 2010. The R Project for statistical computing. Vienna, Austria. [online] URL: http://www.r-pro ject.org/

Roman-Cuesta, R. M., N. Salinas, H. Asbjornsen, I. Oliveras, V. Huaman, Y. Gutierrez, L. Puelles, J. Kala, D. Yabar, M. Rojas, R. Astete, D. Y. Jordan, M. Silman, R. Mosandl, M. Weber, B. Stimm, S. Gunter, T. Knoke, and Y. Malhi. 2011. Implications of fires on carbon budgets in Andean cloud montane forest: the importance of peat soils and tree resprouting. Forest Ecology and Management 261:19871997. http://dx.doi.org/10.1016/j.foreco.2011.02.025

Sanon, H. O., C. Kabore-Zoungrana, and I. Ledin. 2007. Behaviour of goats, sheep and cattle and their selection of browse species on natural pasture in a Sahelian area. Small Ruminant Research 67:64-74. http://dx.doi.org/10.1016/j.sm allrumres.2005.09.025

Seleshi, Y., and G. R. Demaree. 1995. Rainfall variability in the Ethiopian and Eritrean highlands and its links with the Southern Oscillation Index. Journal of Biogeography 22:945952. http://dx.doi.org/10.2307/2845995
Shaffer, L. J. 2010. Indigenous fire use to manage savanna landscapes in southern Mozambique. Fire Ecology 6:43-59. http://dx.doi.org/10.4996/fireecology.0602043

Sletto, B. 2009. 'Indigenous people don't have boundaries': reborderings, fire management, and productions of authenticities in indigenous landscapes. Cultural Geographies 16:253-277. http://dx.doi.org/10.1177/1474474008101519

Solomon, T. B., H. A. Snyman, and G. N. Smit. 2007. Cattlerangeland management practices and perceptions of pastoralists towards rangeland degradation in the Borana zone of southern Ethiopia. Journal of Environmental Management 82:481-494. http://dx.doi.org/10.1016/j.jenvman.2006.01.008

Stocks, B. J., B. D. Lawson, M. E. Alexander, C. E. Van Wagner, R. S. McAlpine, T. J. Lynham, and D. E. Dube. 1989. Canadian forest fire danger rating system-an overview. Forestry Chronicle 65:258-265.

Storm, L., and D. Shebitz. 2006. Evaluating the purpose, extent, and ecological restoration applications of indigenous burning practices in southwestern Washington. Ecological Restoration 24:256-268. http://dx.doi.org/10.3368/er.24.4.256

Vial, F., C. Sillero-Zubiri, J. Marino, D. T. Haydon, and D. W. Macdonald. 2010. An analysis of long-term trends in the abundance of domestic livestock and free-roaming dogs in the Bale Mountains National Park, Ethiopia. African Journal of Ecology 49:91-102. http://dx.doi.org/10.1111/j.1365-2028.20 10.01233.x

Viegas, D. X., G. Bovio, A. Ferreira, A. Nosenzo, and B. Sol. 1999. Comparative study of various methods of fire danger evaluation in southern Europe. International Journal of Wildland Fire 9:235-246. http://dx.doi.org/10.1071/WF00015

Wesche, K., A. Cierjacks, Y. Assefa, S. Wagner, M. Fetene, and I. Hensen. 2008. Recruitment of trees at tropical alpine treelines: Erica in Africa versus Polylepis in South America. Plant Ecology \& Diversity 1:35-46.

Wesche, K., G. Miehe, and M. Kaeppeli. 2000. The significance of fire for afroalpine ericaceous vegetation. Mountain Research and Development 20:340-347. http://dx. doi.org/10.1659/0276-4741(2000)020[0340:TSOFFA]2.0.CO;2

Yimer, F., S. Ledin, and A. Abdelkadir. 2006. Soil property variations in relation to topographic aspect and vegetation community in the south-eastern highlands of Ethiopia. Forest Ecology and Management 232:90-99. http://dx.doi.org/10.1016/ j.foreco.2006.05.055 